\title{
Radial Basis Function Neural Network sebagai Pengklasifikasi Citra Cacat Pengelasan
}

\author{
Noorman Rinanto (1), Mohammad Thoriq Wahyudi (2), Agus Khumaidi (3) \\ 1,3 Program Studi Teknik Otomasi, Politeknik Perkapalan Negeri Surabaya \\ ${ }^{2}$ Program Studi Teknik Pengelasan, Politeknik Perkapalan Negeri Surabaya \\ ${ }^{1}$ noorman.rinanto@ppns.ac.id
}

\begin{abstract}
ABSTRAK
Tingginya resiko kesalahan manusia dalam inspeksi visual untuk cacat pengelasan yang masih mengandalkan kemampuan manusia sulit untuk dihindari. Oleh sebab itu, penelitian ini mengusulkan sebuah klasifikasi cacat las visual dengan menggunakan algoritma Radial Basis Function Neural Network (RBFNN). Masukan RBFNN berupa citra las yang terdiri dari 5 (lima) kelas cacat las visual dan 1 (satu) kelas citra las normal. Citra las tersebut diproses terlebih dahulu menggunakan metode ekstraksi fitur Fast Fourier Transform (FFT) dan Descreate Cosine Transform (DCT). Hasil kedua metode ekstraksi fitur tersebut kemudian akan saling dibandingkan untuk mengetahui kinerja RBFNN. Hasil pengujian menunjukkan bahwa sistem dengan metode FFT-RBFNN dapat menggolongkan citra cacat las dengan akurasi sebesar $91.67 \%$ dan DCT-RBFNN sekitar $83.33 \%$ dengan jumlah neuron hidden layer sebanyak 15 dan parameter spread adalah 4.
\end{abstract}

Kata Kunci: Radial Basis Function Neural Network (RBFNN), FFT, DCT, cacat las, klasifikasi.

Radial Basis Function Neural Network as a Weld Defect Classifiers

\begin{abstract}
The high risk of human error in visual inspection of welding defects that still rely on human capabilities is difficult to avoid. Therefore, this study proposes a classification of visual welding defects using the Radial Base Function Neural Network (RBFNN) algorithm. The RBFNN input is in the form of a welding image consisting of 5 (five) visual welding defect classes and 1 (one) normal welding image class. The weld image is processed first using the Fast Fourier Transform (FFT) and Descreate Cosine Transform (DCT) feature extraction methods. The results of these two feature extraction methods will be compared to find out the RBFNN performance. The test results show that the system with FFT-RBFNN method can classify the image of weld defects with an accuracy of $91.67 \%$ and DCT-RBFNN around $83.33 \%$ with the number of hidden layer neurons as much as 15 and the parameters of spread are 4.
\end{abstract}

Keywords: Radial Basis Function Neural Network (RBFNN), FFT, DCT, weld defect, classification. 


\section{PENDAHULUAN}

Pemeriksaan terhadap hasil pengelasan (Welding Inspection) sangat diperlukan untuk mengetahui kualitas dan tingkat kelayakan terhadap specimen pengelasan. Banyak sekali metode yang digunakan untuk memeriksa hasil pengelasan, secara garis besar dibagi menjadi 2 (dua) tipe yaitu Destructive Testing (DT) atau pemeriksaan hasil las dengan merusak spicemen las dan Non Destructive Testing (NDT) yang tidak merusak hasil las.

$$
\text { Visual Testing (VT) }
$$

merupakan salah satu metode inspeksi hasil pengelasan yang termasuk kategori NDT yang paling popular dibanding dengan metode lain seperti Magnetic Particle Inspection Testing (MT), Liquid (Dye) Penetrant Inspection (PT), $X$ Ray Inspection Testing (RT), Ultrasonic Testing (UT), Air or water pressure Testing (LT) (NDT Education Resource Center, 2001). Metode-metode tersebut sering digunakan sebagai pengujian awal hasil pengelasan sebelum dilakukan metode pengujian yang lain. Pengujian ini hanya membutuhkan seorang ahli inspeksi las untuk mengamati specimen hasil pengelasan. Permasalahan tingkat ketelitian dan pengalaman sering menjadi kendala dari seorang ahli inspeksi las dalam melakukan pekerjaannya. Hal tersebut dipengaruhi oleh tingkat konsentrasi dan lamanya jam terbang seorang ahli inspeksi las dalam melakukan pengamatan. Oleh sebab itu, penelitian ini mengusulkan sebuah alat bantu berupa perangkat lunak untuk menggolongkan jenis cacat pengelasan visual dari citra las hasil capture kamera.

Diharapkan penelitian ini dapat membantu ahli inspeksi pengelasan untuk mengambil keputusan yang tepat saat memeriksa hasil specimen las.

Penelitian sebelumnya yang berkaitan dengan inspeksi hasil las menggunakan citra las hasil foto radiografi telah banyak dilakukan oleh para peneliti (X. Zhang et al, 2005), (F. Mekhalfa et al., 2014), (D.Gao et al., 2006), (J. Shao et al., 2011). Penelitian tersebut melakukan klasifikasi cacat las dari citra radiografi pengelasan dengan algoritma Support Vector Machine (SVM).

Penelitian lainnya dengan metode berbasis fuzzy logic banyak diterapkan pada citra las radiografi seperti pendeteksian cacat crack pada citra las radiografi menggunakan Fuzzy Support Vector Machine (FSVM) dan transformasi beamlet dilakukan oleh Sun dan tim (Z. Sun et al., 2009), kemudian klasifikasi citra las radiografi menggunakan metode fuzzy KNN yang dilakukan oleh Liao (T. W. Liao, 2003) dan penelitian dengan metode Adaptive Network based Fuzzy Inference System (ANFIS) yang diusulkan oleh Vilar (R.Vilar, 2009).

Metode Neural Network (NN) pada citra las radiografi telah banyak dilakukan, seperti penelitian Boaretto (N. Boaretto et al., 2016) yang menggunakan metode Multilayer Perceptron (MLP) untuk mendeteksi citra las pada jalur perpipaan. Kemudian tim peneliti Nacereddine ( $\mathrm{N}$. Nacereddine et al., 2005) dan Mirapeix (J. Mirapeix et al., 2007) mengusulkan klasifikasi dengan menggunakan Principal Component Analysis (PCA) dengan NN. Pendekatan lain untuk klasifikasi citra las radiografi menggunakan fitur geometri dan tekstur pernah diinisiasi oleh Valavanis (I. Valavanis, 2010). 


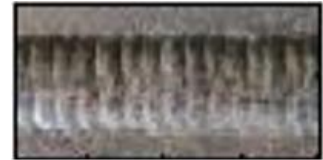

(a)

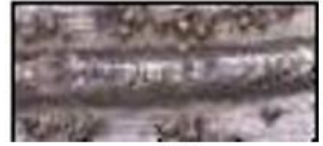

(d)

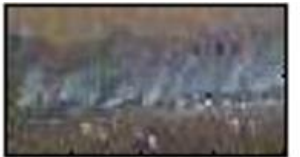

(b)

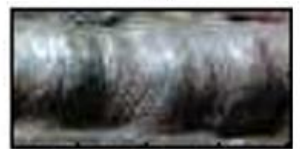

(e)

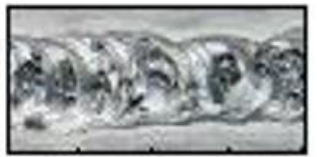

(c)

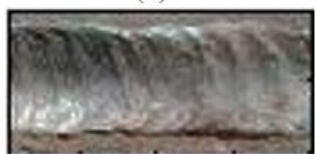

(f)

Gambar 1

Contoh citra las dalam beberapa kategori (a) normal, (b) excessive, (c) porosity, (c) spatter, (d) undercut, (e) underfill

Selain menggunakan citra las, penelitian tentang cacat las juga memanfaatkan hasil signal dari pemeriksaan sinyal ultrasonik menggunakan metode kurva koefisien wavelet (K. Sudheera, 2013).

Namun, masih sedikit penelitian mengenai klasifikasi cacat las yang menggunakan citra las hasil foto kamera, seperti yang diusulkan oleh Ranjana (R. Ranjana et al., 2016) dan Khumaidi (A. Khumaidi et al., 2017). Untuk itu, penelitian ini berusaha menggali informasi lebih dalam tentang pengolahan citra las yang dihasilkan oleh kamera digital dengan menggunakan metode Radial Basis Function Neural Network (RBFNN) sebagai classifier. Selain itu, pada penelitian ini digunakan Fast Fourier Transform (FFT) serta Discrete Cosines Transform (DCT) sebagai metode awal untuk mendapatkan fitur dari citra las masukan.

Citra las yang digunakan pada paper ini sekitar $50 \%$ diperoleh dari hasil foto kamera specimen las di laboratorium pengelasan dan sisanya merupakan foto dari internet. Total keseluruhan jumlah sampel citra sebanyak 30 sampel las dengan 18 sampel digunakan sebagai citra latih sistem dan sisanya untuk keperluan pengujian sistem. Setiap citra las tersebut terlebih dahulu diberikan label kategori yang terdiri dari (normal, excessive, porosity, spatter, undercut, underfill) oleh seorang ahli inspeksi las. Keenam contoh kategori citra las yang digunakan penelitian ini seperti ditunjukkan pada Gambar 1.

\section{METODE PENELITIAN}

Implementasi sistem yang diusulkan pada penelitian ini, secara umum terbagi menjadi 4 (empat) tahapan utama yaitu Preprocessing, Ekstraksi fitur (FFT dan DCT), Konversi Citra Biner, dan RBFNN.

\section{a. Preprocessing}

Citra-citra hasil pengelasan yang digunakan pada penelitian ini, terlebih dahulu harus melalui tahap pemrosesan awal (preprocessing) dengan tujuan untuk mengurangi gangguan yang muncul pada citra serta untuk menyeragamkan besarnya ukuran citra. Adapun skema pemrosesan awal citra tersebut seperti ditunjukkan pada Gambar 2. 


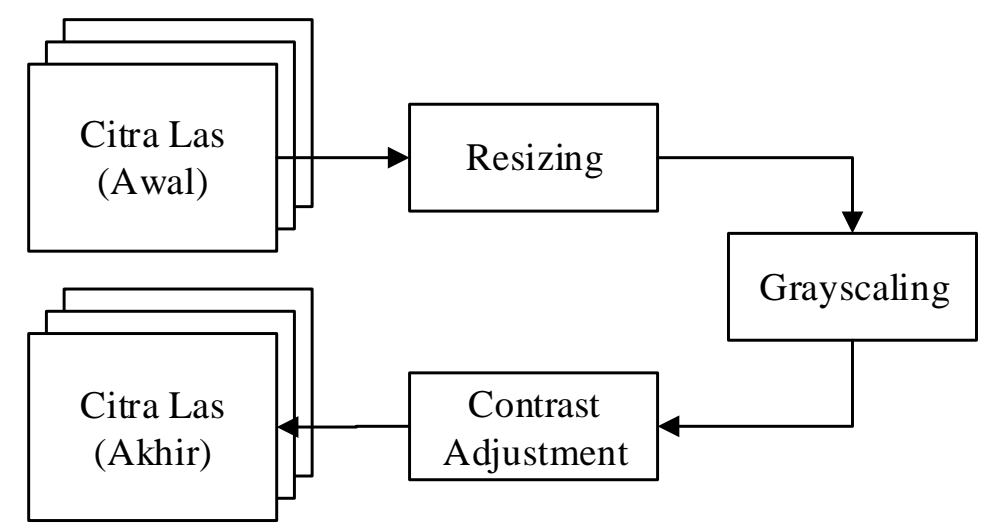

Gambar 2. Skema preprocessing citra las

Gambar 2 menunjukkan bahwa tahapan preprocessing citra las pada penelitian ini dimulai dari proses Resizing atau penyesuaian ukuran resolusi citra las menjadi sebuah citra berukuran $80 \times 40$ piksel. Proses tersebut dilakukan dengan teknik manual menggunakan tools pengolahan gambar yang umum dipakai. Penyesuaian ukuran citra las tersebut bertujuan untuk mengurangi banyaknya variasi ukuran citra las yang digunakan pada penelitian ini. Variasi tersebut muncul akibat sampel diambil dari dua sumber data yang berbeda. Sumber pertama berasal dari foto spicemen las menggunakan kamera digital dan sumber data lain diambil dari foto-foto las yang ada di internet. Tujuan digunakannya citra las dari kedua sumber tersebut adalah untuk menguji kehandalan sistem yang diusulkan ini terhadap variasi citra las yang ada.

Langkah selanjutnya adalah proses grayscaling atau pengubahan citra las yang semula berformat Red Green Blue (RGB) menjadi citra keabu-abuan (grayscale). Pengubahan format citra tersebut bertujuan untuk mengurangi tingkat kompleksitas data warna berformat RGB. Perhitungan grayscale yang digunakan pada penelitian ini menggunakan rumus seperti ditunjukkan pada persamaan (1) (A. Kadir, 2012).

$I=0.2989 R+0.5870 G+0.1141 B$

Dengan I merupakan nilai warna grayscale, $\boldsymbol{R}$ merupakan warna komponen merah, sedangkan $\boldsymbol{G}$ merupakan warna warna komponen hijau dan $\boldsymbol{B}$ merupakan warna komponen biru.

Setelah didapatkan citra las berformat grayscale, proses selanjutnya adalah contrast adjustment atau pengaturan kontras dari citra las. Proses tersebut bertujuan untuk mendapatkan citra las yang mempunyai kualitas intensitas pencahayaan yang sesuai. Pengaturan kontras ini berdasarakan nilai standard deviation (SD) (D. Chang, 1998) yang didapatkan dari nilai warna citra las. Formula yang digunakan seperti yang ditunjukkan pada persamaan (2).

$$
\mu-f . S<C<\mu+f . S
$$

Dimana, $\boldsymbol{C}$ merupakan warna citra las yang masuk kedalam range yang diinginkan. $\boldsymbol{f}$ adalah nilai konstanta pengali yang berupa bilangan bulat positif, pada penelitian ini digunakan nilai $\boldsymbol{f}=2$. Variabel $\boldsymbol{S}$ merupakan nilai SD dari warna citra las yang nilainya didapat dari 
persamaan (3). Sedangkan $\boldsymbol{\mu}$ adalah nilai warna rata-rata dari matrik citra las yang diperoleh dari persamaan (4).

$$
\begin{aligned}
& S=\sqrt{\frac{1}{N-1} \sum_{i=1}^{N}\left|A_{i}-\mu\right|^{2}} \\
& \mu=\frac{1}{N} \sum_{i=1}^{N} A_{i}
\end{aligned}
$$

Dengan $\boldsymbol{A}$ merupakan vektor variabel dari warna citra las tiap piksel, $\boldsymbol{i}$ merupakan nomor indeks piksel dan $\boldsymbol{N}$ adalah jumlah data piksel citra las yang diobservasi, Keluaran dari proses pengaturan kontras ini merupakan citra las yang sudah dinormalisasikan dan siap dipakai untuk tahap ekstraksi fitur selanjutnya.

\section{a. Ekstraksi fitur}

Proses ekstraksi fitur merupakan tahapan yang bertujuan untuk mendapatkan pola ciri dari citra las setiap kategori cacat visual. Metode ekstraksi yang dipakai pada penelitian ini terdiri dari 2 (dua) macam metode yaitu metode yang berbasis FFT dan metode yang berbasis DCT. Kedua metode tersebut digunakan secara terpisah karena nantinya citra yang dihasilkan kedua metode tersebut akan dibandingkan dengan mengujinya ke algoritma RBFNN. Masukan kedua metode ekstraksi fitur tersebut berupa semua citra las sampel yang telah melalui tahapan preprocessing.

\section{Fast Fourier Transform (FFT)}

Ekstraksi fitur dengan metode 2D FFT pada penelitian ini dilakukan terhadap citra-citra las hasil preprocessing dengan menggunakan persamaan (5).

$A(\Omega, \Psi)=\sum_{m=-\infty}^{+\infty} \sum_{n=-\infty}^{+\infty} a[m, n] e^{-j(\Omega m+\Psi n) A}(5)$

Dimana, $\boldsymbol{A}(\boldsymbol{\Omega}, \boldsymbol{\Psi})$ merupakan hasil persamaan 2D FFT dalam bentuk diskrit dari citra asli dengan besaran magnitude dan fase sesuai dengan persamaan (6).

$$
A(\Omega, \Psi)=|A(\Omega, \Psi)| e^{j \varphi(\Omega, \Psi)}
$$

\section{Discrete Cosines Transform (DCT)}

Selanjutnya ekstraksi fitur yang diterapkan pada sistem yang diusulkan yaitu metode DCT. Secara umum metode DCT berkaitan dengan Discrete Fourier Transform (DFT), dimana transformasi dua dimensi (2D) DFT sama dengan satu dimensi (1D) DCT yang dikenakan pada sepanjang sebuah dimensi tunggal yang diikuti oleh 1D DCT pada dimensi lain. Definisi dari 2D DCT untuk sebuah masukan citra $A$ dan keluaran citra B seperti ditunjukkan pada persamaan (7).

$$
B_{p q}=\propto_{p} \propto_{q} \sum_{m=0}^{M-1} \sum_{n=0}^{N-1} A_{m n} \cos (x) \cos (y)(7)
$$

Dengan nilai $\boldsymbol{x}$ dan $\boldsymbol{y}$ sesuai dengan persamaan (8) dan persamaan (9).

$$
\begin{array}{ll}
x & \frac{\pi(2 m+1) p}{2 M}, \begin{array}{c}
0 \leq p \leq M-1 \\
0 \leq q \leq N-1
\end{array} \\
y & \frac{\pi(2 n+1) q}{2 N}, \begin{array}{l}
0 \leq p \leq M-1 \\
0 \leq q \leq N-1
\end{array}
\end{array}
$$

Dimana parameter $\propto_{p}$ diperoleh dari persamaan (10). Sedangkan pada parameter $\propto_{\boldsymbol{q}}$ didapatkan dengan menggunakan persamaan (11).

$$
\begin{gathered}
\propto_{p} \\
=\left\{\begin{array}{l}
\frac{1}{\sqrt{M}}, p=0 \\
\sqrt{\frac{2}{M}}, 1 \leq p \leq M-1
\end{array}\right. \\
\propto_{q}=\left\{\begin{array}{l}
\frac{1}{\sqrt{N}}, q=0 \\
\sqrt{\frac{2}{N}}, 1 \leq q \leq N-1
\end{array}\right.
\end{gathered}
$$


Dengan $\boldsymbol{M}$ dan $\boldsymbol{N}$ adalah ukuran baris dan kolom dari citra $\boldsymbol{A}$ secara berurutan.

\section{b. Konversi Citra Biner}

Setelah dilakukan proses ekstraksi fitur, maka langkah selanjutnya adalah dengan mengubah citra las hasil ekstraksi menjadi citra yang berformat biner. Proses konversi citra ini berbasis nilai threshold tingkat keabuan yang mempunyai range antara 0 dan 1 . Untuk mendapatkan citra biner dilakukan perhitungan dengan menggunakan persamaan (12).

$B_{p q}=\left\{\begin{array}{l}A_{m n} \geq \varnothing, 1 \\ A_{m n}<\varnothing, 0\end{array}\right.$

Dengan $\boldsymbol{A}_{\boldsymbol{m} \boldsymbol{n}}$ merupakan citra masukan, dan $\boldsymbol{B}_{\boldsymbol{p} \boldsymbol{q}}$ adalah citra hasil konversi biner dengan $\emptyset$ sebagai nilai threshold. Sedangkan $\boldsymbol{p}, \boldsymbol{q}$ dan $\boldsymbol{m}, \boldsymbol{n}$ merupakan jumlah piksel citra dalam baris dan kolom. Jika warna citra $A$ melebihi nilai $\emptyset$, maka warna citra $B$ diberi nilai 1 dan begitu sebaliknya. Nilai keluran 1 merupakan putih dan nilai 0 adalah warna hitam. Nilai $\emptyset$ yang digunakan pada penelitian ini adalah 0.5 .

\section{c. RBFNN}

Seluruh Citra biner yang dihasilkan dari proses sebelumnya baik menggunakan metode FFT dan
DCT, kemudian dibagi menjadi dua bagian yaitu sampel citra biner yang akan dipakai untuk proses pelatihan (learning) algoritma RBFNN sebanyak $60 \%$ dari total 64 sampel dan sisanya digunakan untuk proses pengujian (testing).

Algoritma RBFNN merupakan keluarga dari metode Multi-Layer Perceptron Neural Network (MLPNN) yang mempunyai kemampuan dalam mengestimasi sebuah fungsi yang non-linier. Hal tersebut dibuktikan dengan beberapa penelitian yang membandingkan kinerja antara MLPNN dan RBFNN, seperti yang dilakukan oleh Mak (M. W. Mak et al., 1993) dan Ghorbani (M. A. Ghorbani et al., 2016). Perbedaan mendasar antara kedua metode tersebut, terletak pada fungsi aktifasi pada lapisan tersembunyi hidden layer. MLPNN menggunakan fungsi aktifasi sigmoid dan RBFNN menggunakan fungsi aktifasi Gaussian seperti ditunjukkan pada persamaan (13) ().

$\varphi(r)=e\left(-\propto_{i} \cdot\left\|x-c_{i}\right\|^{2}\right)$

Dimana, $\boldsymbol{\varphi}$ merupakan Radial Basis function, $\propto_{i}$ adalah parameter Spread, $\boldsymbol{x}$ yaitu vektor data masukan, dan $\boldsymbol{c}_{\boldsymbol{i}}$ berupa vektor tengah dari $\boldsymbol{i}^{\text {th }}$ neuron.

Sedangkan konstruksi dari algoritma RBFNN yang diusulkan pada penelitian ini, seperti ditunjukkan pada Gambar 3.

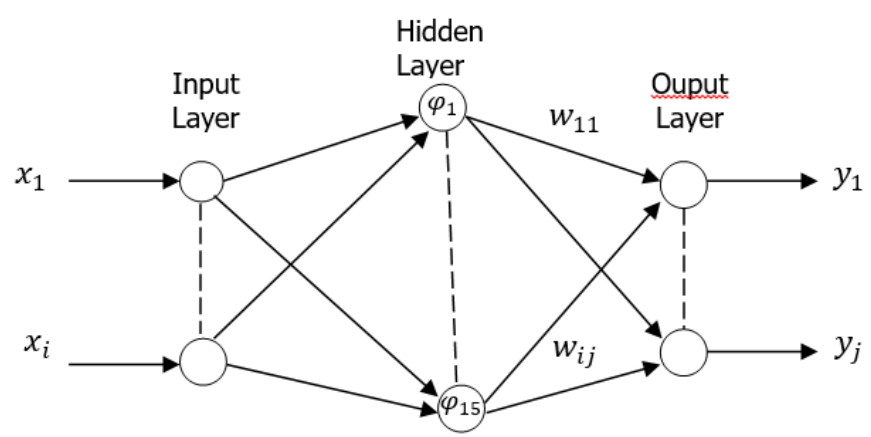

Gambar 3. Kontruksi RBFNN 


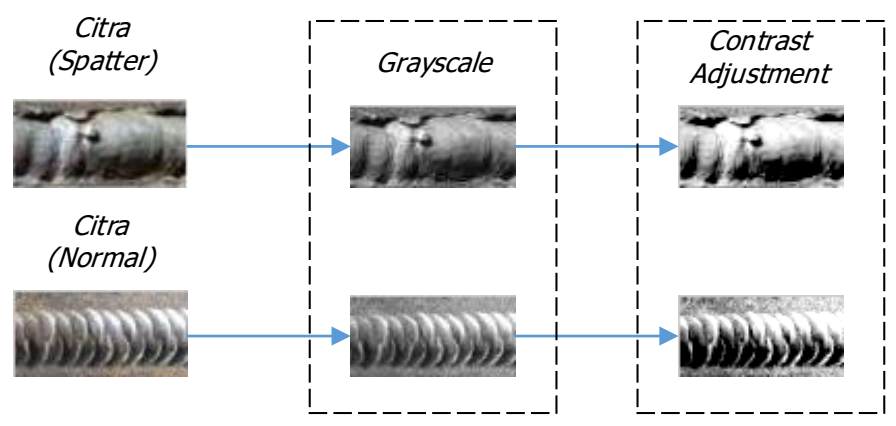

Gambar 4. Hasil pemrosesan preprocessing citra las

Jumlah masukan sistem RBFNN (i) berjumlah 3200 data yang merepresentasikan jumlah piksel citra las berukuran $80 \times 40$ piksel. Jumlah lapisan tersebunyi sekitar 15 node. Sedangkan jumlah keluaran sistem tersebut (j) berjumlah 6 yang mewakili keenam kategori citra cacat las.

Secara umum perhitungan nilai keluaran dari sistem klasifikasi yang diusulkan ini seperti ditunjukkan pada persamaan (14).

$y_{j}=\sum_{i=1}^{I} w_{i j} \varphi+\beta_{j}$

Dimana, $\boldsymbol{i}$ merupakan jumlah neuron pada lapisan tersembunyi, $\boldsymbol{j}$ adalah jumlah neuron pada lapisan keluaran, $\boldsymbol{w}_{i j}$ sebagai bobot neuron pada lapisan tersebunyi dan lapisan keluaran, dan $\boldsymbol{\beta}_{\boldsymbol{j}}$ adalah nilai bias lapisan keluaran. Sedangkan $\boldsymbol{y}_{\boldsymbol{j}}$ adalah nilai keluaran dari metode RBFNN.

\section{HASIL DAN PEMBAHASAN}

Untuk mengetahui kinerja dari sistem pada penelitian ini, maka hasil-hasil setiap tahap utama perlu diperiksa dan di analisa.

\section{Hasil preprocessing}

Gambar 4 menunjukkan beberapa contoh hasil tahapan preprocessing citra las untuk subproses Grayscaling dan Contrast Adjustment yang telah melalui proses Resizing citra. Pada gambar tersebut ditampilkan dua buah contoh sampel citra las yaitu sampel citra yang berkategori cacat spatter dan citra las yang normal.

\section{Hasil Ekstraksi fitur}

Contoh hasil proses ekstraksi fitur dari citra las menggunakan metode 2D FFT seperti ditunjukkan pada Gambar 5. Sedangkan contoh hasil pemrosesan yang melalui metode ekstraksi fitur 2D DCT seperti ditunjukkan pada Gambar 6. Dari kedua gambar tersebut, tampak sekali perbedaan citra hasil ekstraksi antara citra las yang normal dengan citra las yang dikategorikan cacat spatter.

\section{Hasil Konversi Citra Biner}

Tahapan selanjutnya setelah ekstrasi fitur yaitu proses konversi citra las menjadi citra biner yang nantinya akan menjadi masukan dari sistem klasifikasi RBFNN. Contoh hasil konversi citra biner dari citra fitur 2D FFT seperti ditunjukkan pad Gambar 7. Sedangkan Gambar 8 menunjukkan hasil citra biner yang berasal dari citra masukan fitur 2D DCT. 


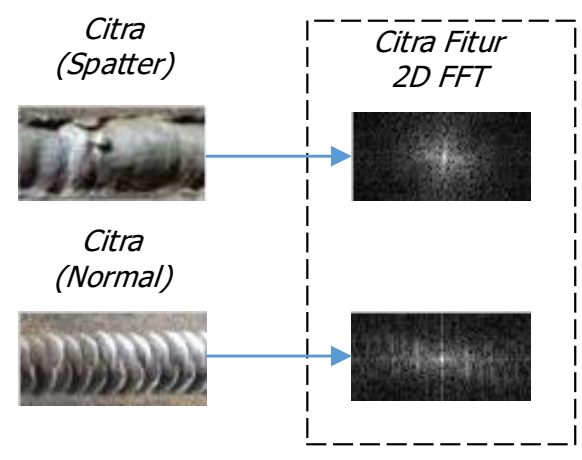

Gambar 5

Hasil ekstraksi fitur citra las dengan 2D FFT

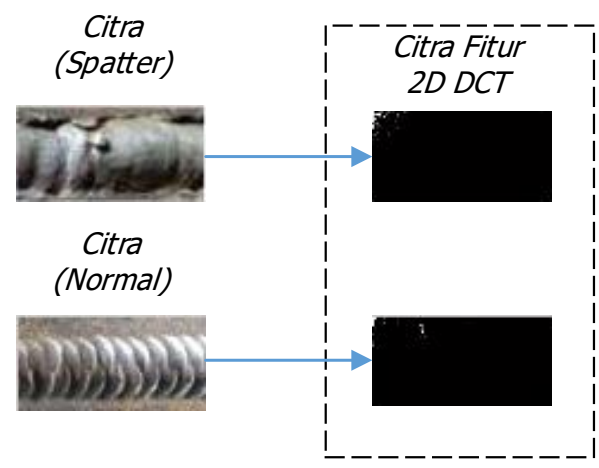

Gambar 6

\section{Hasil ekstraksi fitur citra las dengan 2D DCT}

Setelah diperoleh citra biner dari kedua metode ekstraksi fitur (2D FFT dan 2D DCT), maka langkah selanjutnya adalah menguji sampelsampel tersebut ke dalam sistem klasifikasi RBFNN.

\section{Hasil RBFNN}

Sebelum citra biner dijadikan masukan sistem RBFNN, citra-citra tersebut baik yang dihasilkan oleh 2D FFT atau 2D DCT dibagi menjadi 2 (dua) kelompok sampel citra biner. Satu kelompok sebanyak 36 sampel dari 64 sampel digunakan untuk data pelatihan dan sisanya digunakan sebagai pengujian. Pemilihan sampel-sampel tersebut dilakukan secara acak. Sebagai catatan, semua sampel tersebut sudah diberi label oleh ahli inspeksi yang berpengalaman dengan kategori cacat yaitu (normal, porosity, spatter, undercut, dan underfill).

Setelah citra dikelompok menjadi dua, maka langkah selanjutnya yaitu proses pelatihan sistem (training) RBFNN. Proses pelatihan ini dilakukan terhadap sampel citra hasil ekstraksi 2D FFT dan citra hasil ekstraksi 2D DCT. Gambar 9 menunjukkan salah satu contoh grafik performa pelatihan sistem ini dengan sampel citra 2D FFT. Sedangkan untuk citra las hasil 2D DCT ditunjukkan pada Gambar 10. Kedua proses pelatihan RBFNN tersebut dilakukan dengan menggunaan parameter RBFNN yang sama, yaitu nilai $s p r e a d=2$, dan jumlah hidden layer sebanyak 10. Kontruksi sistem RBFNN untuk proses pelatihan tersebut seperti ditunjukkan pada Gambar 11. 


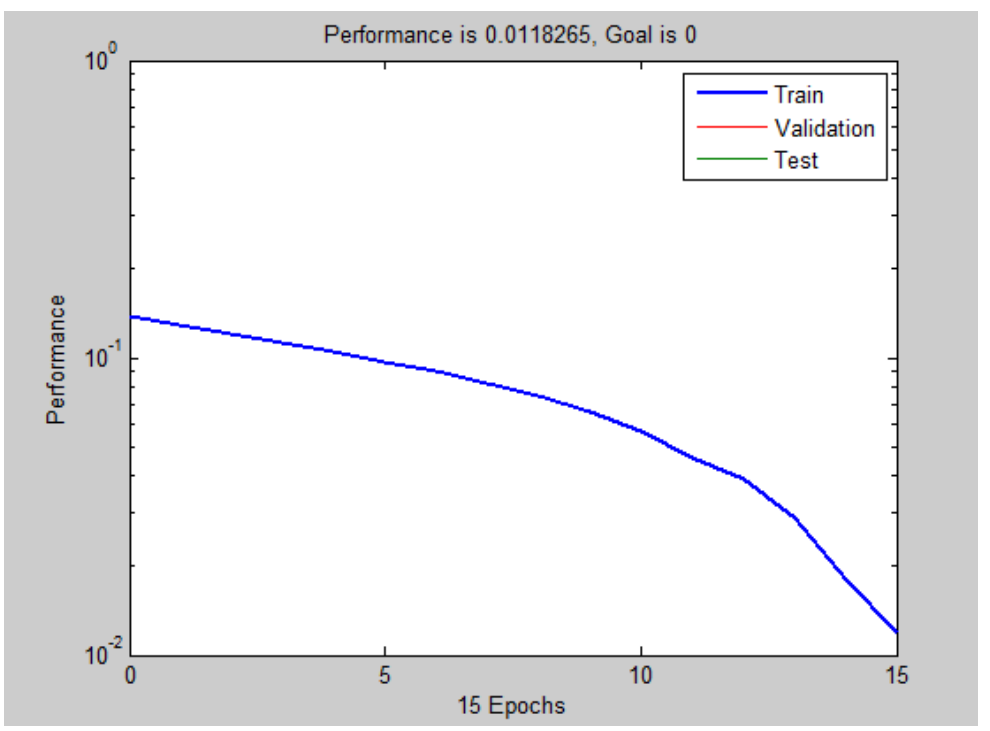

Gambar 9 Grafik performa pelatihan RBFNN dengan citra las 2D FFT

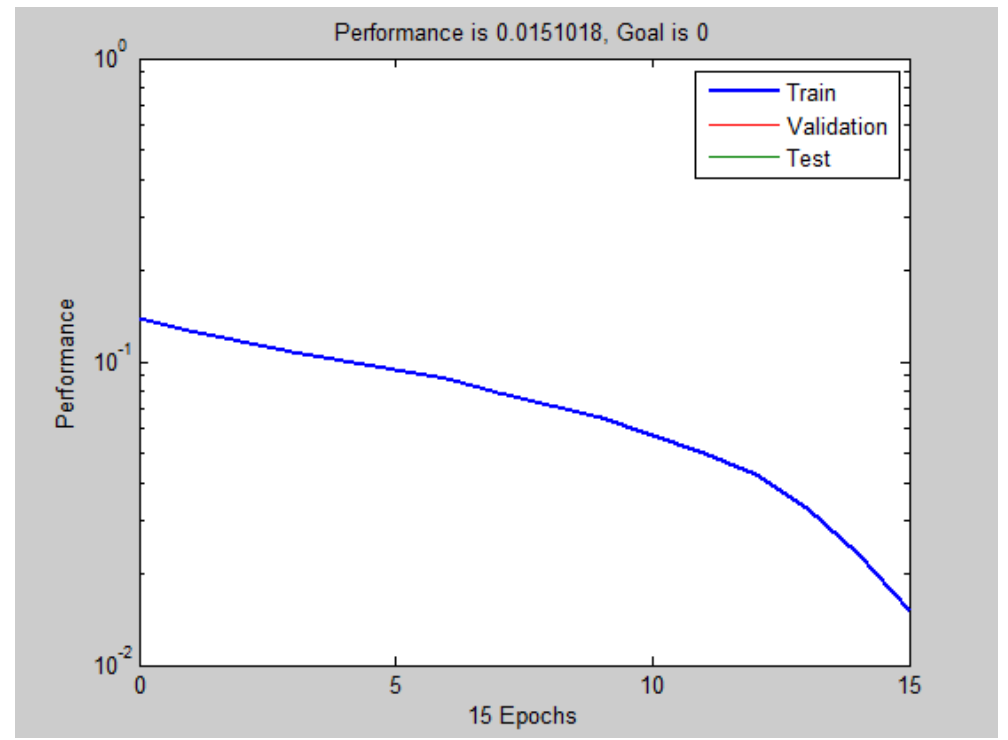

Gambar 10. Grafik performa pelatihan RBFNN dengan citra las 2D DCT

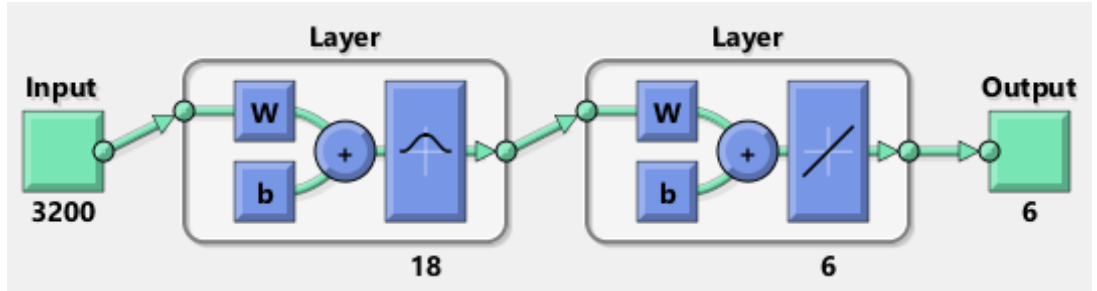

Gambar 11. Kontruksi sistem RBFNN saat pelatihan 
Dari kedua grafik uji coba kinerja seperti ditunjukkan pada Gambar 9 dan Gambar 10, diketahui bahwa kedua sampel berhenti pada nilai epoch $=15$, namun nilai Mean Square Error (MSE) citra DCTRBFNN mempunyai nilai 0.0032753 lebih besar dibanding citra FFTRBFNN. Untuk mengetahui hasil yang lebih jauh, maka dilakukan uji coba performa kedua sistem dengan mengubah parameter spread dengan jumlah neuron hidden layer $=18$, yang hasilnya seperti ditunjukkan pada Tabel 1.

Setelah diperoleh nilai spread yang mempunyai nilai MSE rendah untuk keduanya, maka dipilih nilai spread $=4$. Dari data pengujian pada Tabel 1 tersebut, maka dapat dibuat grafik perbandingan pengaruh perubahan nilai parameter spread pada sistem FFT-RBFNN dan DCTRBFNN seperti ditunjukkan pada Gambar 12.

Tabel 1

Perbandingan kinerja FFT-RBFNN dan DCT-RBFNN terhadap perubahan nilai spread

\begin{tabular}{|c|c|c|c|c|}
\hline \multirow{2}{*}{$\begin{array}{l}\text { Jumlah } \\
\text { Spread }\end{array}$} & \multicolumn{2}{|c|}{ MSE } & \multicolumn{2}{|c|}{ Epoch } \\
\hline & FFT-RBFNN & DCT-RBFNN & $\begin{array}{c}\text { FFT- } \\
\text { RBFNN }\end{array}$ & $\begin{array}{c}\text { DCT- } \\
\text { RBFNN }\end{array}$ \\
\hline 1 & 0.0123454 & 0.0184735 & 15 & 15 \\
\hline 2 & 0.0118265 & 0.0151018 & 15 & 15 \\
\hline 3 & 0.0115477 & 0.0125825 & 15 & 15 \\
\hline 4 & 0.011512 & 0.0113885 & 15 & 15 \\
\hline 5 & 0.0117787 & 0.0148838 & 15 & 15 \\
\hline 6 & 0.00895269 & 0.0145888 & 15 & 15 \\
\hline 7 & 0.00899951 & 0.0143997 & 15 & 15 \\
\hline
\end{tabular}

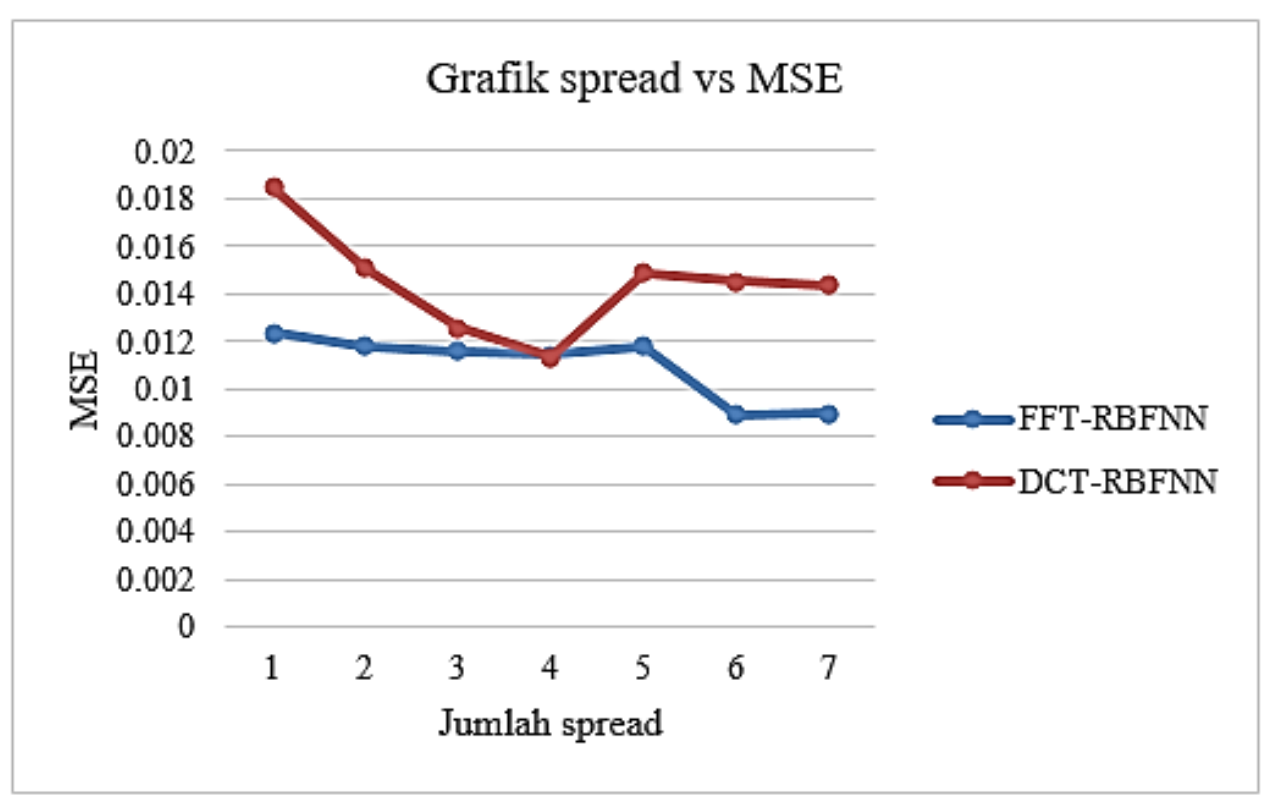

Gambar 12

Grafik pengaruh nilai spread pada FFT-RBFNN dan DCT-RBFNN 
Pengujian selanjutnya adalah dengan mengubah jumlah hidden layer dengan nilai spread $=4$ dan hasilnya seperti ditunjukkan pada Tabel 2.

Berdasarkan data pengujian pada Tabel 2, maka grafik perbandingan sistem FFT-RBFNN dan DCT-RBFNN terhadap pengaruh perubahan jumlah neuron pada lapisan tersembunyi seperti ditunjukkan pada Gambar 13.

Dari Gambar 13 diketahui bahwa kedua sistem mengalami nilai MSE yang konstan saat jumlah neuron hidden layer diatas 15. Sehingga pada penelitian ini dipakai jumlah neuron hidden layer sebesar 15 dan dari pengujian sebelumnya diperoleh nilai $s p r e a d=4$.

Tabel 2

Perbandingan kinerja FFT-RBFNN dan DCT-RBFNN terhadap perubahan jumlah neuron hidden layer

\begin{tabular}{clccc}
\hline \multirow{2}{*}{$\begin{array}{c}\text { Jumlah } \\
\text { neuron }\end{array}$} & \multicolumn{2}{c}{ MSE } & \multicolumn{2}{c}{ Epoch } \\
\cline { 2 - 5 } & FFT-RBFNN & DCT-RBFNN & $\begin{array}{c}\text { FFT- } \\
\text { RBFNN }\end{array}$ & $\begin{array}{c}\text { DCT- } \\
\text { RBFNN }\end{array}$ \\
\hline 5 & 0.0812638 & 0.0862284 & 5 & 5 \\
10 & 0.045432 & 0.0538004 & 10 & 10 \\
15 & 0.011512 & 0.0113885 & 15 & 15 \\
20 & 0.011512 & 0.0113885 & 15 & 15 \\
\hline
\end{tabular}

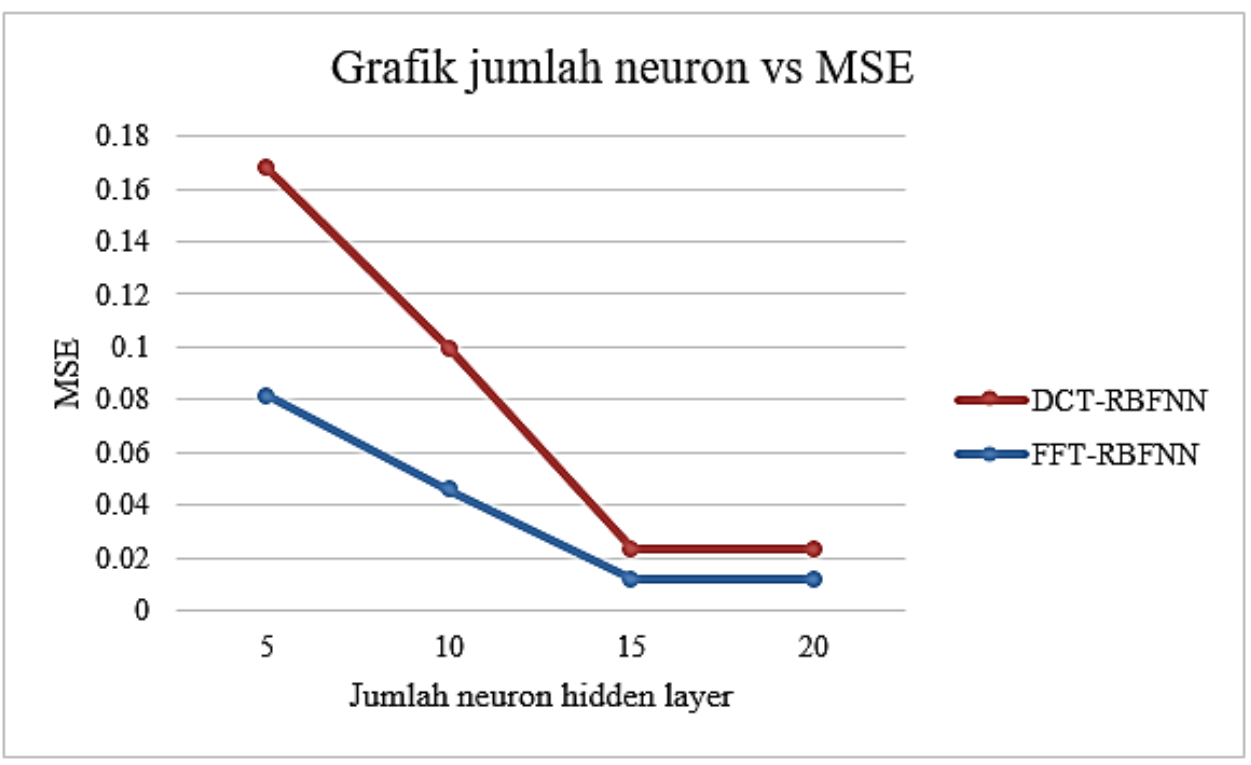

\section{Gambar 13 \\ Grafik pengaruh jumlah neuron hidden layer terhadap sistem FFT-RBFNN dan DCT-RBFNN}

Selanjutnya fase yang harus dilalui adalah pengujian terhadap sampel yang bukan termasuk kelompok data pelatihan. Jumlah total sampel yang dipakai ada 24 sampel dengan 12 sampel citra hasil ekstraksi fitur 2D FFT dan sisanya citra hasil ekstraksi 2D DCT. Sehingga setiap kategori citra cacat las terdiri dari 2 sampel dari 6 kategori cacat las visual. Hasil pengujian ini disajikkkan pada Tabel 3. 
Tabel 2

Perbandingan hasil pengujian FFT-RBFNN dan DCT-RBFNN

\begin{tabular}{ccccc}
\hline $\begin{array}{c}\text { Jumlah } \\
\text { neuron }\end{array}$ & \multicolumn{2}{c}{ MSE } & \multicolumn{2}{c}{ Akurasi (\%) } \\
\cline { 2 - 5 } & FFT-RBFNN & DCT-RBFNN & $\begin{array}{c}\text { FFT- } \\
\text { RBFNN }\end{array}$ & $\begin{array}{c}\text { DCT- } \\
\text { RBFNN }\end{array}$ \\
\hline 10 & 0.045432 & 0.0538004 & 83.33 & 75 \\
15 & 0.011512 & 0.0113885 & 91.67 & 83.33 \\
\hline
\end{tabular}

Berdasarkan hasil pengujian pada Tabel 3, diketahui bahwa sistem FFT-RBFNN mempunyai akurasi $8.37 \%$ lebih baik dibanding sistem DCT-RBFNN.

\section{KESIMPULAN}

Penelitian ini menyajikan sebuah metode klasifikasi cacat las visual berbasis Radial Basis Function Neural Network (RBFNN) dengan masukan sistem berupa citra las hasil foto dengan metode ekstraksi fitur 2D FFT dan 2D DCT. Berdasarkan pengujian sistem didapatkan nilai parameter spread yang ideal yaitu 4 dan jumlah neuron pada lapisan

\section{DAFTAR PUSTAKA}

NDT Education Resource Center
(2001). About NDT.
https://www.nde-
ed.org/AboutNDT/aboutndt.
htm, Tanggal akses 4
Februari 2018.

X. Zhang, Z. Zhu, J. Xu, \& S. Ren (2005). The Classification Algorithm of Defects in Weld Image based on Asymmetrical SVMs. Proceeding of International Conference on Control and Automation (ICCA2005), pp. 1215-1219.

F. Mekhalfa \& N. Nacereddine (2014). Multiclass Classification of Weld Defects in Radiographic Images Based on Support Vector Machines. Proceeding of tersembunyi sebanyak 15 . Dari perbandingan kinerja sistem yang menggunakan metode FFT-RBFNN diperoleh akurasi sebesar $91.67 \%$ dan sistem dengan metode DCTRBFNN mempunyai akurasi sekitar $83.33 \%$ atau dengan kata lain citra las yang menggunakan ekstraksi fitur 2D FFT lebih baik dibandingkan dengan citra las yang diekstrak dengan 2D DCT. Sedangkan prosentase akurasi tersebut menunjukkan bahwa sistem yang diusulkan pada penelitian ini mampu menggolongkan cacat las visual dari citra las hasil foto kamera.

Tenth International Conference on Signal-Image Technology \& Internet-Based Systems, pp. 1-6.

D. Gao, Y. Liu, X. Zhang, \& Y. Liu (2006). Binary-tree MultiClassifier for Welding Defects and Its Application Based on SVM. Proceeding of the 6th World Congress on Intelligent Control and Automation, Dalian, China, pp. 8509-8513.

J. Shao, H. Shi, D. Du, L. Wang, \& H. Cao (2011). Automatic Weld Defect Detection in Real-time X-ray Images Based on Support Vector Machine. Proceeding of 4th International Congress on Image and Signal Processing, pp. 1842-1846. 
Z. Sun, D. Ruan, Y. Ma, X. Hu, \& X. Zhang (2009). Crack Defects Detection in Radiographic Weldment Images using FSVM and Beamlet Transform. Proceeding of Sixth International Conference on Fuzzy Systems and Knowledge Discovery, pp. 402-406.

T. W. Liao (2003). Classification of welding flaw types with fuzzy experts systems. Expert Systems with Applications, vol. 25(1), pp. 101-111.

R.Vilar, J. Zapata, and R. Ruiz (2009). An automatic system of classification of weld defects in radiographic images. NDT\&E International, vol. 42(5), pp. 467-476.

N. Boaretto \& T. M. Centeno (2016). Automated detection of welding defects in pipelines from radiographic images DWDI. NDT and $E$ International, http://dx.doi.org/10.1016/j.ndt eint.2016.11.003, Tanggal akses 12 Mei 2018.

N. Nacereddine, and M. Tridi (2005). Computer-aided shape analysis and classification of weld defects in industrial radiography based invariant attributes and neural networks. Proceeding of the 4 International Symposium on Image and Signal Processing and Analysis ISPA, pp. 88-93.

J. Mirapeix, P. B. Garcia-Allende, A. Cobo, O. M. Conde, and J. M. Lspez-Higuera (2007). Real time arc welding defect detection and classification with principal component analysis and artificial neural networks.

NDT\&E
International, vol. 40(4), pp. 315-323.

I. Valavanis, and D. Kosmopoulos (2010), Multiclass defect detection and classification in weld radiographic images using geometric and texture features. Expert Systems with Applications, vol. 37, pp. 7606-7614.

K. Sudheera, N. M. Nandhitha, P. Nanekar, B. Venkatraman, \& B. S. Rani (2013). Automated Weld Defect Classification Ultrasonic Signals using statistical moments on normal distribution curves of Wavelet co-efficient. Proceeding of International Conference on Advanced Electronic System (ICAES), pp. 24-28.

R. Ranjana, A. Reza Khan, C. Parikh, R. Jain, R. P. Mahto, S. Pal, S. K. Pal, \& D. Chakravarty (2016). Classification and identification of surface defects in friction stir welding An image processing approach. Journal of Manufacturing Processes vol. 22, pp. 237-253.

A. Khumaidi, E. M. Yuniarno, M. H. Purnomo (2017). Welding Defect Classification Based on Convolution Neural Network (CNN) and Gaussian Kernel. Proceeding of International Seminar on Intelligent Technology and Its Application, pp. 261-265.

A. Kadir, and A. Susanto (2012). Pengolahan Citra, Penerbit ANDI Offset, Yogyakarta.

D. Chang, and W. Wu (1998). Image Contrast Enhancement Based on a Histogram Transformation of Local Standard Deviation. Journal 
IEEE Transactions on Medical Imaging, vol. 17(4), pp. 518-531.

M. A. Ghorbani, H. A. Zadeh, M. Isazadeh, \& O. Terzi (2016). A Comparative study of artificial neural network (MLP, RBF) and support vector machine models for river flow prediction. Journal Enviromental Earth Sciences vol.75, pp. 476.

M. W. Mak, and G. G. Sexton (1993). Comparing Multi-Layer
Perceptrons and Radial Basis Functions networks in speaker recognition. Journal of Microcomputer Applications, vol.16(2), pp. 147-159.

T. Kurban, and E. Beşdok (2009). A Comparison of RBF Neural Network Training Algorithms for Inertial Sensor Based Terrain Classification. Sensors 2009, vol. 9, pp. 6312-6329. 